\title{
THE MIDDLE AND LOWER LEVEL EMPLOYEES MOTIVATION IN MONGOLIAN BANKING SECTOR
}

\author{
Enkhbayar B. ${ }^{1 *}$, Zhu Bixiang ${ }^{2}$ \\ ${ }^{I}$ Nanjing University of Science\& Technology, China \\ ${ }^{2}$ Nanjing University of Science\& Technology, China \\ * corresponding author, e-mail: enkhbayar0799@gmail.com
}

ARTICLE INFO: Received: 10 Nov, 2017; Revised: 18 Dec, 2017; Accepted: 25 Dec, 2017

\begin{abstract}
All organizations, whether they produce services or products have people in the process. Further, the organizations ability to have motivated employees will determine the success of failure of that organization (Bergmann \& Scarpello, 2001). Here the study focuses on motivation as one of the most important factors that may contribute to employee performance has been examined in relation to banking sector in Mongolia. It will be observed in this study what is the most important factors that motivate employees are, respectively, "Existence Needs", "Relatedness Needs" and "Growth Needs" by ERG motivation theory Alderfer. Even though the priority of these needs differ from person to person, Alderfer's ERG theory prioritises in terms of the categories' concreteness. The main objective of this study was to "assess the role of motivation of the middle and lower level employees" in banking sector of Mongolia. The survey was designed to get answers on what they consider the best factors that could motivate them as future employees motivation. The analysis of the results showed that job satisfaction is the most matched.
\end{abstract}

Keywords: Motivation; human behavior; productivity; Mongolia; Banking sector; Middle and Lower level employee;

\section{INTRODUCTION}

Motivation is a core element of management in human resources. There is no similarities in qualities, feelings and behaviors of employees so it is some difficult to take care of human being with varying characteristics and qualities. Without motivation, organization could not run long time. It is more important for human resources to activate, train and develop all motivated in order that make individual and organization goals. Every single employee has skills, abilities and knowledge, if there is not added motivation, would not open a way of success, if there is added motivation, would open a way of success for an organization. There are various sources of motivation by which can motivate the staff, such as good pay, provision of decent accommodation, good condition of service and opportunity for staff training, and motivated employees can increase their productive capacity.

Motivational factors can be further categorized in two categories one is factor that do not present in any organization and another one is factors presents but does not motivate.

Category 1:

- Recognition

- Achievement

- Advancement

- Responsibility

- Possibility of Growth

- Work itself 
Category 2:

- Company Policies and administration

- Technical supervision

- Interpersonal relationship with colleagues

- Interpersonal relationship with superior

- Interpersonal relationship with subordinate

- Salary

- Working Environment

- Personal Life

- Status

- Job Security

- Fringes and Benefits

\section{Objective of the study}

The main objective of the paper is to study about the different motivational factors that are involved in Middle and Lower level's employee satisfaction in banking sector of Mongolia. There are certain another reasons which carried out as a result of this paper.

- To find which motivational factor is more important.

- To understand about the employees satisfaction level.

- To develop and identify the level of satisfaction so that HR policies can be revised with reference to that.

Delimitations: This study will be limited to measuring bank employees in Trade and Development Bank of Mongolia. The study will measure what motivates the bank employees according to their own attitude. Hence, the study will not measure how motivated the employees at the banks measured are.

\section{Mongolian banking sector}

Current situation of Mongolian Banking Sector. Mongolia's banking system has become more efficient and reliable, although supervision lags and some banks do not measure up to international standards. Prior to 1991, no western-style commercial or central banking system existed in Mongolia. The State Bank was the only bank in Mongolia. In October 1990, the Mongolian Government, in line with free market economic reforms, dissolved the State Bank. In 1991, Mongolia enacted a new banking law to create a westernstyle banking system. The law re-organized the banking system into a two-tier structure. During all this time 17 banks went bankrupt and the system as a whole has successfully survived system-wide crises in 1998 and 2008. The Bank of Mongolia, or Mongol Bank, acts as the central bank, implementing monetary policy. Other private and public banks provide commercial services. Mongolia's four largest commercial banks are: Golomt Bank, Khan Bank ,Trade and Development Bank, Xac Bank.

According to the consolidated balance sheet of the banks of Mongolia, the total assets of the bank reached to MNT25,159,2 billion at the end of March 2017, which increased by $18.8 \%$ year on year level. Currently 14 commercial banks are operating in the banking sector through their 1492 branches and almost 14 thousand banking staff deliver wide range of banking services, and the banking sector as a whole has become one of the largest sectors of the economy.1 From this point of view, The survey was designed to get answers to what they consider the best factors that could motivate them as future employees from factors of motivation in Trade and Development Bank as a case of Mongolian one of the best bank. For almost 50 years, Euromoney has been the leading publication for covering the growth of international finance markets. Trade and Development Bank of Mongolia has received "Mongolia's Best Bank 2017" award during the Euromoney Awards for Excellence 2017 ceremony. "These are difficult times for Mongolian banks, with the whole economy having been hit by the end of the commodity boom, but Trade and Development Bank (TDB) is coming out of the situation in the best shape. Primarily a commercial bank, it holds $43.3 \%$ of the corporate lending sector in Mongolia, including a strong position in micro and SME lending. It has also built dominant positions in the domestic money market, foreign exchange 
and gold. A capital adequacy ratio of $14.6 \%$ is among the best in the industry - and this is no time for a bank to have anything less than robust capital positions."2

The recent slowdown in Mongolia's growth due to lower commodities prices and slower growth in China has brought a significant decline in jobs and a rapid rise in unemployment. Even during the economic boom between 2010 and 2014, the unemployment rate stayed relatively elevated and rarely dropped below 7 percent. Informal employment - often through low-level selfemployment -also continues to be widespread. In 2017, There is 23576 workers are working in banking and financial sector.

\section{Trade and Development Bank of Mongolia}

Trade and Development Bank (TDB) LLC was established in 1990 and over past decades, has become a leading banking and financial services provider in Mongolia.

Trade and Development bank is the oldest bank of Mongolia. In 2016 , In order to support career development of the current employees, 58 percent of the vacant positions were filled by existing employees and number of the promoted employees were increased by 27 percent, indicating that one out of ten employees of the bank was promoted. As a result of implementing the policy of encouraging current employees to work with stability and efficiently, average employment year of the bank was increased to 6 years, which was 8 months increase compared to the last year. There is many operation of training the employees and implemented numerous programs, ensuring their personal growth. For example: Succession program;Career development program;Program to develop future Senior managers and Directors;Program to improve foreign language skills Total of 226 training sessions were conducted this year and 4,483 (recurring number) employees were attended the sessions.

\section{Salary and social welfare}

By improving salary system, successfully completing the work of matching it with the performance of each employee and utilizing important tool of promoting the non-salary incentive, state orders and medals were awarded to total of 18.6 percent of the employees. Moreover, we have provided various supports to young employees, implementing apartment allocation program and other programs directed to employees families. Besides, State Social Insurance General Office highly valued TDB's human resource management and awarded TDB with "Best national employer - best paying institution of social security payment" in 2016.

Literature review: Employee's motivation is one of the important aspects in today's dynamic world because, if your employee will not motivated the overall performance of your company can be affected, in result company's mission and objective will be overlap. Joint contribution of employees will surely take the company to the new horizons. Complex and challenging job are not a big matter if your employees are truly motivated "Movere" is the Latin word from which motivating origins; it means "to move" all though it might say something about what motivation is. It is by far not enough to describe its meaning in this context. Muchinsky, (1993) defines motivation as "Motivation is the individual's desire to demonstrate the behavior and reflects willingness to expend effort" (Muchinsky, 1993, p.323). There are many different definitions of motivation and among them three common characteristics can be identified. First, what energizes human behavior. Second, what directs this behavior. Third, how such a behavior is sustained (Porter, Bigley \& Steers, 2003). This thesis will mainly look the first characteristic, what energizes human behavior. Motivation can be divided in two different types, extrinsic and intrinsic motivation. 
Extrinsic motivation refers to external factors, which can be measured in monetary terms, such as salary and benefits (Aronson, Wilson \& Akert, 2002). Intrinsic motivation refers to internal factors such as job satisfaction. The two different factors are connected to each other and cannot be seen in isolation (Frey \& Osterloh, 2002)."

\section{a. Clayton P. Alderfer's ERG theory}

Clayton P. Alderfer's ERG theory from 1969 condenses Maslow's five human needs into three categories: Existence, Relatedness and Growth.

\section{Existence Needs}

Include all material and physiological desires (e.g., food, water, air, clothing, safety, physical love and affection). Maslow's first two levels.

\section{Relatedness Needs}

Encompass social and external esteem; relationships with significant others like family, friends, co-workers and employers . This also means to be recognized and feel secure as part of a group or family. Maslow's third and fourth levels.

Growth Needs

Internal esteem and self-actualization; these

\section{MATERIAL AND METHODS}

A survey has been taken by employees in banks and it is measured that at what level motivational factors are needed in different situation and in different level. Quota sampling was used to select 250 people from Middle and Lower level employees of Trade and Development Bank of Mongolia. Twenty five detailed sets of questionnaires were designed to collect primary data from the bank employees by Alderfer's ERG theory such as working conditions, promotion /expectation, styles/ organization management, team spirit, job satisfaction, recognition, working hours, goals attainment, salary and benefit. All the analysis has been done manually and the result impel a person to make creative or productive effects on himself and the environment (e.g., to progress toward one's ideal self). Maslow's fourth and fifth levels. This includes desires to be creative and productive, and to complete meaningful tasks.

Even though the priority of these needs differ from person to person, Alberger's ERG theory prioritises in terms of the categories' concreteness. Existence needs are the most concrete, and easiest to verify. Relatedness needs are less concrete than existence needs, which depend on a relationship between two or more people. Finally, growth needs are the least concrete in that their specific objectives depend on the uniqueness of each person.

\section{b. Sexes and hypothesis formulation}

It is important to define sex in this thesis since it can have many meanings and are frequently use in the thesis. Hence, a definition of sex will be give. In the second sub chapter theory regarding differences between men and women in the work place will be presented and compared to the motivational theory described above. From the comparisons between these different theories two hypotheses will be drawn

is taken in percentage of all individuals. The survey consists of two parts: the first part, the basic information of bank employees (eg age, job title, education level, etc.), and the second part, a total of 25 question and answer questions. The 25 questions are respectively related to three kinds of ERG theories (1 to 12 questions belong to the survival needs $\mathrm{E} ; 13$ to 17 questions belong to the relationship R; 18 to 25 questions belong to the growth needs G). Different degrees of approval correspond to different scores, the specific evaluation criteria are divided into: very unsatisfied -1 , less than -2 , basically satisfied -3 , more satisfied -4 , very satisfied -5 . 


\section{Q1-12}

Q13-17

Q18-25

\section{ANALYSIS AND DISCUSSION}

Most of the emloyees are between 27-35 bachelor -77.6 percent and above Master ages (60 percent) and 68 percent is woman and 32 percent is men. About the education degree -19.8 percent.

Table 1. Descriptive Statistical Analysis of Different Dimensions of Incentive Satisfaction

\begin{tabular}{cccc}
\hline & $\mathrm{E}$ & $\mathrm{R}$ & $\mathrm{G}$ \\
\hline Value & 2.9420 & 3.0372 & 2.9818 \\
Standard deviation & 0.79637 & 0.87749 & 0.80438 \\
Variance & 0.634 & 0.770 & 0.647 \\
\hline
\end{tabular}

In table number 1 is a descriptive statistical analysis of the three dimensions of the employees' incentive satisfaction of the Trade and Development Bank of Mongolia. The mean and standard deviation of each variable is in a reasonable range, and data analysis can be carried out well. The existence of incentive satisfaction (E) value was 2.9420, less than 3, indicating the measured staff on the survival motivation factors bank satisfaction is still not satisfied, the relationship between incentive satisfaction $(\mathrm{R})$ value was 3.0372 , more than 3 employees, that measured on the banks of the relationship between motivation factors satisfaction bias, growth incentive the mean of 2.9818, less than 3, indicating the measured employee satisfaction degree is not satisfied with the growth of the bank's incentive factors.

Table 2. Single factor analysis of variance

\begin{tabular}{ccccccc}
\hline & & N & Means & Standard deviation & F & Significance \\
\hline \multirow{2}{*}{ E } & Male & 169 & 2.8609 & 0.78389 & \multirow{2}{*}{5.644} & 0.018 \\
& Female & 78 & 3.1175 & 0.79992 & & \\
\multirow{2}{*}{ R } & Male & 169 & 2.9408 & 0.87030 & \multirow{2}{*}{6.609} & 0.011 \\
& Female & 78 & 3.2462 & 0.86185 & & \\
\multirow{2}{*}{ G } & Male & 169 & 2.8824 & 0.79569 & \multirow{2}{*}{8.416} & 0.004 \\
& Female & 78 & 3.1971 & 0.78555 & & \\
\hline
\end{tabular}

From the table we can see that, Trade and Development Bank of Mongolia, men's mean satisfaction of subsistence, relationship and growth incentive are less than 3, representing their dissatisfaction with the bank's incentives, women's survival, relationships and The average satisfaction of growth incentive is higher than 3, which means that they are satisfied with all the bank's incentives. Among them, the significant $<0.05$ on growth incentive satisfaction indicates that gender has a significant impact on the growth incentive satisfaction. 
Table 3. Single factor variance analysis by working period

\begin{tabular}{|c|c|c|c|c|c|c|}
\hline & & $\mathrm{N}$ & Means & $\begin{array}{l}\text { Standard } \\
\text { deviation }\end{array}$ & $\mathrm{F}$ & Significance \\
\hline \multirow{4}{*}{$\mathrm{E}$} & Less than 3 years & 92 & 2.8306 & 0.77992 & \multirow{4}{*}{1.211} & \multirow{5}{*}{0.306} \\
\hline & $3-5$ years & 99 & 2.9731 & 0.72588 & & \\
\hline & 6-10years & 42 & 3.0992 & 0.87425 & & \\
\hline & 10 years above & 14 & 2.9821 & 1.08810 & & \\
\hline \multirow{4}{*}{$\mathrm{R}$} & Less than 3 years & 92 & 3.0022 & 0.87127 & \multirow{4}{*}{0.684} & \\
\hline & $3-5$ years & 99 & 3.0081 & 0.80403 & & \multirow[t]{3}{*}{0.563} \\
\hline & 6-10years & 42 & 3.0810 & 0.99075 & & \\
\hline & 10 years above & 14 & 3.3429 & 1.07968 & & \\
\hline \multirow{4}{*}{ G } & Less than 3 years & 92 & 2.9022 & 0.78966 & \multirow{4}{*}{1.143} & \multirow{4}{*}{0.333} \\
\hline & $3-5$ years & 99 & 2.9646 & 0.74724 & & \\
\hline & 6-10years & 42 & 3.1131 & 0.88552 & & \\
\hline & 10 years above & 14 & 3.2321 & 1.01297 & & \\
\hline
\end{tabular}

\section{CONCLUSION}

It is accepted that the motivation of employee in serving customers plays an important role to make customer happy in banking industry. The survey shows that one of the most important factors in the labor force in Mongolia is remuneration. Wages in Mongolia increased to 966.61 MNT Thousand/Month in the second quarter of 2017 from 959.14 MNT Thousand/Month in the first quarter of 2017. Comparing banking sector and other factor's average wages, Banking sector is better than others and ranking 4th of most important sector in Mongolia. 3

The main purpose of this paper to evaluate the role of work motivation in the employee's performance. The motivation of the employees is a necessity for all organizations performance. This study sought to define the motivational factors for the employees of the bank. The respondents in this study rated the top five factors that motivate as future employees as follows: job satisfaction, promotions / expectations, recognition, good pay, and styles of organization / management. Through this study we can conclude that the relatively large foreign banks are smaller than the smaller ones of the Trade and Development bank of Mongolia. Therefore, insufficient economic resources, human resources management department is simple. Owing to the simple organizational structure, the use of subsistence incentive is mainly limited by promotion and salary increase. Therefore, the leadership and charisma of departmental leaders are the most cost-effective incentives for staff motivation. Therefore, by strengthening the ability of leaders to meet the employee's relationship needs, through the establishment of a clear and feasible interest-bound plan and It is a more feasible method to strengthen the bank's cultural construction so as to motivate employees. 


\section{REFERENCES}

1. The report of Banking supervision department, The Bank of Mongolia ,Ulaanbaatar, 2017

2. Euromoney Magazine, Mongolian best banks, 2017

Retrieved from: http://www.tdbm.mn/en/1145/news

3. Trading economics Magazine, Mongolian Wages, 2017/12/14

Retrieved from: https://tradingeconomics.com/mongolia/wages

4. The report of Trade and Developing Bank of Mongolia , 2016

5. A.H. Maslow "A Theory of Human Motivation", p370-96,1943

Retrieved from: http://psychclassics.yorku.ca/Maslow/motivation.htm.

6. $\quad$ Frederick Herzberg, "Work and the Nature of Man", Cleveland: World Publishing, 1996

7. Frederick Herzberg, "One More Time: How Do You Motivate Employees?", Harvard Business Review, Vol. 46, No. 1, Pp. 53-62,1968

8. J. Richard Hackman \& Greg R. Oldham, "Motivation through the Design of Work: Test of a Theory", Organizational Behavior and Human Performance, Vol. 16, No. 2, p. $250-279,1976$

9. K.C.Chakrabarty, "Human Resource management in banks", 2015

10. Competitiveness of Mongolian banking sector, Ulaanbaatar, 2016 Available from: http://mba.mn/mongolian-banking-sector-competitiveness-eng-post/

11. Mongolian national Statistical Organisation report, Ulaanbaatar,2017 Available from: www.nso.mn 